\title{
16. Genel Türkçe sözlüklerde etimolojik gönderme
}

Yakup YILMAZ1

\begin{abstract}
APA: Yılmaz, Y. (2021). Genel Türkçe sözlüklerde etimolojik gönderme. RumeliDE Dil ve Edebiyat
\end{abstract} Araşttrmaları Dergisi, (23), 248-258. DOI: 10.29000/rumelide.948335.

\section{$\ddot{\mathbf{O} z}$}

Sözlüklerin bir özelliği de madde başı kelimesinin art zamanlı gelişimini vermektir. Art zamanlılık, dilde ihtiyaca göre güncelden öncele doğru anlam ve yapı belirlemede yararlanılan kavramlardır. Sözlüklerde eş anlamlılık, kullanılan kelimelerin o an için anlam karşılıklarını öğrenmek için kullanılan yöntemken; art zamanlılı ise madde başı kelimelerin köklerini, hangi lehçe veya dile ait olduklarını, ne zaman ortaya çıktıklarını, anlam ve yapı bakımından geçirdikleri değişiklikleri öğrenmek için yararlanılan, daha geniş bilgi verme amaçlıdır. Türkçe sözlükler, etimolojik açıklamalar bakımından farklılıklar gösterir. Bu çalışmada taranan sözlükler 1. el ve cep sözlükleri, 2. okul sözlükleri, 3. genel sözlükler, 4. ansiklopedik sözlükler olarak belirlenmiştir. Genel Türkçe sözlükler a. etimolojik açıklama verilmeyenler; b. sadece kaynak dili verilenler; c. kaynak dil ve kaynak kelime verilenler; d. kaynak dil, kaynak kelime ve geniş açıklama verilenler olmak üzere tasnif edilebilir. "Etimolojik açıklama hangi durumlarda gereklidir." sorusuna, "Sözlüklerin işlevleri dikkate alınarak etimolojik açıklama yazılmalı.” cevabı verilmelidir.

Anahtar kelimeler: Sözlük, sözlükçülük, etimoloji, etimolojik açıklama

\section{Etymological reference in general Turkish dictionaries}

\begin{abstract}
One feature of dictionaries is to give the incremental development of the word header. Diachronism is a concept that is used to determine the correct meaning and structure in the language, according to the need, before the current. While it is the method used to learn the meanings of words in which synonyms are used in dictionaries; Diachronism, on the other hand, is a broader informational method used to learn the roots of the head words, which dialect or language they belong to, when they emerged, and the changes they have undergone in terms of meaning and structure. Turkish dictionaries differ in terms of etymological explanations. The dictionaries scanned in this study were determined as 1st hand and pocket dictionaries, 2nd school dictionaries, 3rd general dictionaries, and 4th encyclopedic dictionaries. General Turkish dictionaries a. those without etymological explanation; b. only those whose source language is given; c. source language and source words; D. The source language can be classified as source word and those with broad explanations. "In what situations etymological explanation is required.", "An etymological explanation should be written considering the functions of the dictionaries." The answer should be given.
\end{abstract}

Keywords: Dictionary, lexicography, etymology, etymological explanation

Doç. Dr., İstanbul Medeniyet Üniversitesi, Eğitim Bilimleri Fakültesi, Türkçe ve Sosyal Bilgiler Eğitimi Bölümü, Türkçe Eğitimi ABD (İstanbul, Türkiye), yilmazyakupbey@gmail.com, ORCID ID: 00oo-0oo1-6230-8850 [Araştırma makalesi, Makale kayıt tarihi: 24.04.2021-kabul tarihi: 20.06.2021; DOI: 10.2900o/rumelide.948335]

\section{Adres Address}

RumeliDE Dil ve Edebiyat Araşttrmaları Dergisi $\quad$ RumeliDE Journal of Language and Literature Studies Osmanağa Mahallesi, Mürver Çiçeği Sokak, No:14/8 Osmanağa Mahallesi, Mürver Çiçeği Sokak, No:14/8

Kadıköy - İSTANBUL / TÜRKIYE 34714 Kadıköy - ISTANBUL / TURKEY 34714 e-posta: editor@rumelide.com

e-mail: editor@rumelide.com

tel: +90 $5057958124,+90216773$ o 616 phone: +90 505 7958124, +90 216773 o 616 


\section{Sözlük ve sözlükçülük}

Bilgilenmenin ve bilgiyi saklamanın başladığı, anlamanın kayıtlı hale geldiği zamandan beri kullanılan sözlükler, insanların vazgeçilmez eserleri arasında gelir. Hayatta anlamlandırma ve yapılandırma değiştikçe sözlüklerde görünen anlam ve yapı da değişir. Böylece güncel kalma, ama önceli de unutmama düşüncesi kendisini sözlüklerde gösterir. Bu çalışmada sözlüklerde güncelden öncele işaret veren genel Türkçe sözlükler ele alınmıştır.

\section{Sözlük için şu tanımlar mevcuttur:}

Sözlük, bir dilin bütün veya belli bir çağda kullanılmıș kelime ve deyimlerini alfabe sırasına göre alarak tanımlarını yapan, açıklayan, başka dillerdeki karşılıklarını veren eserdir. (TDK, 2011, s. 2157).

Sözlük, bir dilin ya da bir dilin bir bölümünün genel olarak veya belirli zamanda kullanılan kelime ve deyimlerini umumiyetle alfabe sırasına, bazen de kavram alanlarına göre ele alıp aynı dille tanımlarını yapan, örnek vererek açıklayan veya başka bir dildeki karşılıklarını yazan kitaptır (Kaçalin, 2009, s. 403). Sözlük, eskilerin "tarif" için söyledikleri "efrâdını câmi ağyârını mâni" (gerekenleri içerip gerekmeyenleri dışarıda bırakma) ilkesine uygun olmalıdır (Kaçalin, 2009, s. 403).

Sözlük hazırlamanın bilimi ya da zanaatı olan sözlükçülük, bir dilin veya karşllıklı olarak daha fazla dilin söz varlığını sözlük biçiminde ortaya koymak üzere yöntemleri araştırma; sözlük hazırlama, yazma ilkelerini, kurallarını geliştirme ve uygulama alanına çıkarma işidir (TDK, 2011, s. 2157).

Sözlüklerde ilk aradığımız kayıtlı biçim olan ve en belirgin halde görülen madde başı, sözlük yapma düzeninde başlı başına bir anlam ifade eden ve siyah olarak yazılan, tanımı verilen sözlük birimidir (TDK, 2011, s. 1599). Sözlük hazırlamada en önemli, en çok özen isteyen iş, madde başındaki tanımların verilmesidir. Kolayca yanlışlı̆̆a düşmeye ya da eksik anlatıma çok elverişli olan bu işlem ayrı bir uzmanlığı ve geniş bir kültürü gerektirir (Aksan, 1995, s. 409).

Sözlük hazırlanırken belli hedefler gözetilir. Bu hedefler hazırlayanın niyetine göre değişir. Usta’nın tespitine göre sözlükçülükteki hedefler, ana çizgileriyle, aşağıdaki şekilde sıralanabilir (Usta, 2010, s. 97):

1. Söz varlığının sözlükte tanımlanması için gerekli olan ilke ve usullerin bilimsel hazırlığı, sözlükçülüğün temel hedefidir. Ayrıca, sözcüklerin dildeki farklı görünümlerini ortaya koymaya çalışan sözlüklerin oluşturulması da temel hedeflerden biridir.

2. Sözlüklerin tipolojisini çıkarmak, öncelikli konulardandır. Pratik sözlükçülüğün çağdaş yönelimleri (bilgisayarlaştırma, yararcılık, bilişimsel metot, sözlüklerin toplumsal hedefleri vs.) tipolojinin geliştirilmesinde etkili olmaktadır. Sözlük tipolojisini çıkarmak, sözlükçülüğün genel ilkelerini ortaya koymak için gereklidir.

3. Sözlükçülük teorisi, sözlük yazımı ile yan yana yürüyen gelişme sürecinde, teorik bir disiplin olma yolunda ilerlemektedir. Bu disiplinin belli başlı üç doğrultuda ilerlediği görülmektedir: Eğitimöğretim amaçlı, çok dilli, bilimsel-teknik.

Türkiye Türkçesi söz varllğını yetkin bir biçimde değerlendirememek ve sürekli olarak sözlükteki madde başlarının niceliği üzerinde yoğunlaşmak, sözlük hazırlayıcılarının "yöntem” konusuna yeterince eğilmelerini engellemiş; Türkçe Sözlük, içindeki birçok değerlendirme ve örneklendirme hatası yüzünden işlevselliğini yitirmiştir. Oysaki sözlüklerde "tanımlayıcı, açıklayıcı, doğrulayıcı, önerici, örneklendirici” yönlerin ağırlıkta olması gerekir. Öte yandan sözlüğün hazırlanış amacı ve hedef kitlesinin netleştirilememiş olması da önemli bir etkendir. Bu sorunun kaynağı, sözlükbilimi

\begin{tabular}{r|l} 
Adres & Address \\
RumeliDE Dil ve Edebiyat Araşttrmalar Dergisi & RumeliDE Journal of Language and Literature Studies \\
Osmanağa Mahallesi, Mürver Çiçeği Sokak, No:14/8 & Osmanağa Mahallesi, Mürver Çiçeği Sokak, No:14/8 \\
Kadıköy - İSTANBUL / TÜRKIYY 34714 & Kadıköy - ISTANBUL / TURKEY 34714 \\
e-posta: editor@rumelide.com & e-mail: editor@rumelide.com, \\
phone: +90 505 7958124, +90 2167730616
\end{tabular}


ilkelerinin uygulanmamasında aranmalı ve ona göre çözümler üretilmelidir. Bu amaçla, Türkçe Sözlük’te bir yöntem sorununun bulunduğuna dikkat çekmek isterim (Usta, 2006, s. 226).

Madde başlarında verilen anlamlar hazırlayanın bakışına, dünyayı tanımasına, farklı dünyalara anlam taşıyabilmesine göre değişiklik gösterir. Madde başlarının karşılığı veya açıklaması olan anlamın yapılandırılmasını sağlayacak yöntem ve teknikler sadece anlam karşılamakta kullanılmayıp aynı zamanda hayatın ve kültürün bir izahı olması bakımından önem taşımaktadır (Karadüz, 2009, s. 647648). Dolayısıyla anlam vermede şu özellikler önemlidir ve madde başı açıklamalarında görülmelidir:

a. Sözlüklerde sözcük anlamı verilirken, açıklayıcı anlatım biçimi kullanılır, tanım yapılır.

b. Sözcük anlamının desteklenmesi için örneklendirmeler yapılır. Sözcük anlamının verilmesinde kullanılan örnekler genelde cümle düzeyinde olmaktadır.

c. Sözcük anlamının verilmesinde en çok kullanılan tekniklerden birisi de sözcüğün eş anlamının verilmesidir.

d. Sözcük anlamı verilirken karşıt anlamlılıktan yararlanılır.

e. Resimler yoluyla öğrenme.

f. Örnek olay anlatma.

\section{Genel sözlüklerde kelimelerin etimolojisi}

Genel sözlükler anlam ve yapıları sunma görevini yerine getirmektedir. Bu sözlüklerin bir özelliği de madde başı kelimesinin art zamanlı gelişimini vermektir. Art zamanlılık ve eş anlamlılık, dilde ihtiyaca göre yararlanılan kavramlardır. Sözlüklerde eş anlamlılı mevcut kelimelerin o andaki anlam karşılıklarını öğrenmek için kullanılan yöntemken, art zamanlılık ise madde başı kelimelerin köklerini, hangi lehçe veya dile ait olduklarını, ne zaman ortaya çıktıklarını, ses ve anlam bakımından geçirdikleri değişiklikleri öğrenmek için yararlanılan, daha geniş bilgi verme amaçlı bir yöntemdir.

Etimoloji kelimesi Yunancadan çlkıp Latince yoluyla Fransızcadan Türkçeye geçmiş bir kelimedir. Ayverdi, etimolojiyi bir dildeki kelimelerin köklerini, hangi lehçe veya dile ait olduklarm, ne zaman ortaya çıtıklarını, ses ve anlam bakımından geçirdikleri değişiklikleri inceleyen dil bilimi dah, kök bilimi, köken bilimi, iştikak bilimi, ilm-i iştikak şeklinde tanımlar (Ayverdi İ. , 2011, s. 358).

Etimoloji, dildeki bu tür kelimeleri kökenlerine, değişmelerine ve kaynak dillerine göre inceler ve sözlüklerde etraflıca açıklamaya çalışır. Her etimolojik açıklama doğru kabul edilmez; çünkü etimoloji aslında bir açılama çabasıdır; önceki açıklamalar, doğrular zenginleştikçe yerini daha doğru açıklamalara bırakmak zorundadır.

Genel sözlükler, dilin güncel bütün kelimelerini ele alan, eş anlamlılık yoluyla madde başlarını açıklayan ve sözlükçülükte en yaygın olarak kullanılan sözlüklerdendir. Çok çeşitli örnekleri ve tasnifi görülmektedir. Eminoğlu genel sözlükleri altı kısımda ele almıştır (2010, s. 21):

1. Tek dilli sözlükler,

2. İki dilli sözlükler,

3. İkiden çok dilli sözlükler,

4. Manzum sözlükler,

5. Ansiklopedik sözlükler,

6. Kafiye sözlükleri

\begin{tabular}{|c|c|}
\hline & \\
\hline$D D$ & tudies \\
\hline & er Çiçeği Sokak, No:14/8 \\
\hline $\begin{array}{r}\text { Kadıköy - İSTANBUL / TÜRKIYY } 34714 \\
\text { e-posta: editor@rumelide.com } \\
\text { tel: +90 505 7958124, +90 } 216773 \text { o } 616\end{array}$ & $\begin{array}{l}\text { Kadıköy - ISTANBUL / TURKEY } 34714 \\
\text { e-mail: editor@rumelide.com, } \\
\text { phone: +90 505 7958124, +90 } 216773 \text { o } 616\end{array}$ \\
\hline
\end{tabular}


Kelimeler bir dilde kabaca üçe ayrılır (Sertkaya, 2012, s. 50):

1. Türkçe kökenli kelimeler,

2. Taklidî kelimeler [onomatophe vs.],

3. Yabancı kökenli kelimeler [a) direkt olarak geçen yabancı kökenli kelimeler, b) başka dil üzerinden geçen yabancı kökenli kelimeler].

Türkçenin genel sözlüklerde yer alan kelimelerini madde başı olarak vermek gerektiğinde Türkçe kökenliler, taklidî kelimeler ve yabancı kökenliler olarak sıralamak ve bu sıraya göre açıklamak mümkündür. Bu sözlüklerde hangi açılayıcı bilgilerin olması gerektiği konusunda farklı düşünceler ve uygulamalar vardır.

\section{Türkçe sözlüklerde etimolojik gönderme durumları}

Genel sözlüklerin etimolojik açıklamalarını örneklemek adına aşağıdaki sözlükler incelenmiştir:

1. Sami, Şemseddin (h. 1317). Ḳāmūs-ı Türkī. Dersa'ādet: İḳdām Maṭba'ası.

2. Hüseyin Kâzım (I. 1927, II. 1928, III. 1943, IV. 1945). Türk Lugati. İstanbul: Maarif Matbaası.

3. Doğan, D. M. (1982). Büyük Türkçe Sözlük-Türkçe/Osmanlica/Yabancı Dillerden Türkçeye Geçen ve En Çok Kullanılan Kelimeler (2 b.). Ankara: Birlik.

4. MEB. (1995). Örnekleriyle Türkçe Sözlük (Cilt 2). Ankara: MEB.

5. Dil Derneği (2005). Türkçe Sözlük (2 b.). Ankara: Dil Derneği.

6. Çağbayır, Y. (2007): Orhun Yazıtlarından Günümüze Türkiye Türkçesinin Söz Varlı̆̆ı Ötüken Türkçe Sözlük (Cilt 2). İstanbul: Ötüken.

7. Püsküllüoğlu, A. (2008). Türkçe Sözlük (7 b.). İstanbul: Can.

8. Komisyon. (2011). Türkçe Sözlük. Ankara: TDK.

9. Ayverdi, İlhan (2011). Misalli Büyük Türkçe Sözlük (2. Baskı). İstanbul: Kubbealtı-Milliyet.

\subsection{Sami, Şemseddin (h. 1317). Ķāmūs-ı Türkī. Dersa'ādet: İḳdām Mațba'ası.}

Kamus-ı Türkî o günün konuşma ve yazı dilinde kullanılan Türkçe asıllı kelimelerle birlikte Arapça, Farsça ve Batı kaynaklı kelimeleri de bir araya getiren zengin muhtevalı bir sözlüktür (Uçman, 2010, s. 521-522):

istasyon s. \{Fr. Station\} demir yolu mevkifi. (96. s.)

așil ș. Ar. \{aṣl'dan ṣıfat-ı müşebbehe\} șoylu, aṣıl ve neseb ṣāḥibi, necīb. (124. s.)

3.2. Hüseyin Kâzım (I. 1927, II. 1928, III. 1943, IV. 1945). Türk Lugati. İstanbul: Maarif Matbaası.

I. cildi (İstanbul 1927) XCIX + $4+855$ sayfa,

II. cildi (İstanbul 1928) II + 982 sayfa,

III. cildi (İstanbul 1943) IV + 928 sayfa,

IV. cildi (İstanbul 1945) 894 sayfa

Türk Lugatı esas itibariyle Batı Türkçesinin yanı sıra Uygur, Çağatay, Âzerî ve Kazan lehçeleriyle diğer bazı lehçelerden alınmış kelimelerin etimolojik (kök esasına dayalı), mukayeseli ve edebî (örnekli) bir lugattır. Türk Lugatı’nın tertibi elif harfinden başlayıp ye harfine kadar otuz üç harf üzerinedir. Ebadı

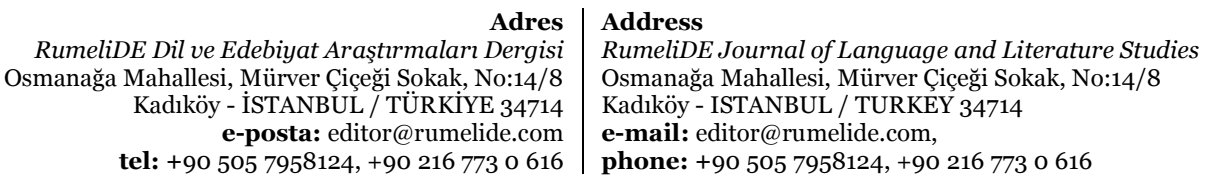


dolayısıyla eserin adı bazı ilmî yayınlarda bile yanlış olarak Büyük Türk Lugatı şeklinde geçmektedir. Sözlük etimolojik ve mukayeseli şekilde hazırlandığı için diğer sözlüklerden ayrılır. Madde başları kelimelerin kök biçimlerinden oluşmakta, türemiş kelimeler bunun altında verilmektedir. Sözlük maddelerinde kelimelerin çeşitli Türk lehçelerindeki biçimleri ayrı ayrı kaydedilmekte, bu maddelerle ilgili örnek metinler, atasözleri ve deyimler yazılmakta, ayrıca yabancı kelimelerin hangi kökten geldiği açıklanmaya çalışılmaktadır. Başka sözlüklerde bulunmayan birçok kelime, terkip ve terimi içermesi eserin zenginliğini ve farklılığını ortaya koymaktadır (Kaçalin M. S., 2012, s. 545).

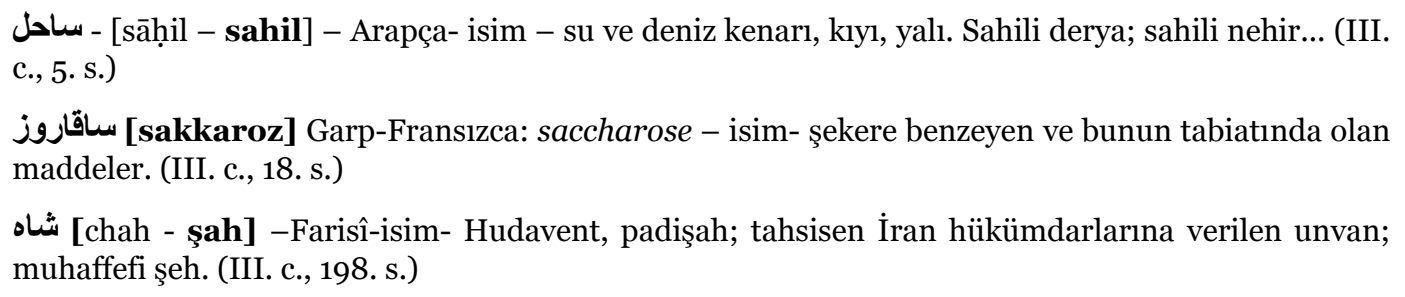

سايماق [saimak - saymak] - Çağatay - müteaddi - saymak; hürmet ve riayet etmek; nazarı dikkat ve itibara almak. (III. c., 34. s.)

\subsection{Doğan, D. M. (1982). Büyük Türkçe Sözlük-Türkçe/Osmanlca/Yabancı Dillerden Türkçeye Geçen ve En Çok Kullanılan Kelimeler (2 b.). Ankara: Birlik.}

İddialı bir adlandırmanın görüldüğü sözlük sözlükçülük sisteminin standart kuralları yerine amatörce bir merakla hazırlanmış görüntüsü vermektedir.

Türkçe kökenli kelimelerde herhangi bir etimolojik gönderme bulunmamaktadır.

Kaynak dili Arapça olan kelimelerin mastar halleri verilmiş, nereden müştak olduğu gösterilmiştir.

câir. /A.s., "cevr"den/ Cevr eden, eziyet yapan. (189. s.)

Farsça kelimelerin de sadece kaynak dil kısaltması verilmiştir.

cambaz. /F.i./ Tehlikeli oyunlar yapan oyuncu,... (189. s.)

Batı dillerinden alınmış kelimelerde de sadece kaynak dilin kısaltması mevcuttur.

levye. /Fr.i./ Kumanda kolu, kaldıraç. (640. s.)

libretto. /İt.i./ Opera güftesi, opera metninin yazlldı̆̆ kitap. (641. s.)

lider. /İng.i./ Önder. Siyasi hareketin başı. (641. s.)

liman. /Yun.i./ Deniz kıyısında gemilerin yük alıp boşalttığı ve firtınalı havalarda sığındığı tabiî veya sun'i barınma yeri. Limanı olan şehir. (641. s.)

\subsection{MEB. (1995). Örnekleriyle Türkçe Sözlük (Cilt 2). Ankara: MEB.}

Madde başının kaynak dili kısaltmalar verilmekle yetinilmiş. Sözlük başında kısaltmalar listesi mevcut. Madde başları biçim değiştirmişse bu tür kelimelerin bazılarının asıl biçimleri parantez içinde verilmiştir. Sadece Arapça ve Farsça kaynaklı kelimeler uzunluklarına dikkat edilerek yazılmış, batı kaynaklı kelimelerin asli imlası yer almamıştır.

ganîmet (ġanīmet) i.A. 1. Savaşta düşmandan alınan mal, para vb. (952. s.)

ganyan s.i.Fr. 1. At yarışlarında kazanan (at). 2. Yarışı kazanan at için alınan bilet. (952. s.)

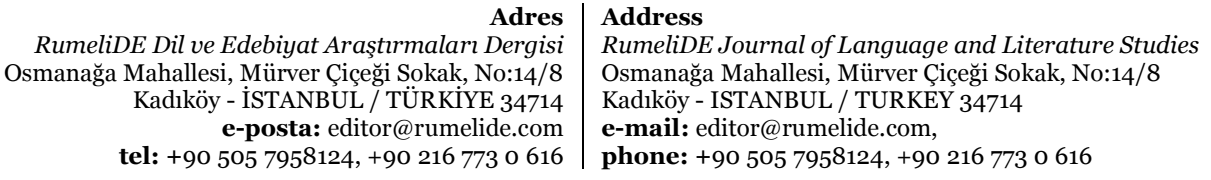


killer i.İng. Üretildikleri kültür ortamına, hemen hemen bütün öteki terliksi hayvan türleri için zehirli bir madde olan terliksi hayvanlara verilen ad. (1691. s.)

gardenya i.Lat. Sicak bölgelerde yetişen bir çeşit ağaç ve bu ağacın güzel kokulu çiçeği. (953. s.)

Biçim ve ses değişimi yaşayan kelimelerde kaynak dildeki asli biçim verilmiş, değişiklik yaşanmayan kelimelerde gerek duyulmamıştır:

kilit i.F. 1. Kapı, sandık, dolap, çanta vb. şeyleri kapamaya ve kapalı olduğu zaman anahtarla açmaya yarayan âlet.

gergef (kā-gāh) i.F. 1. Üzerine kumaş gerilerek nakış işlemeye yarayan, umumiyetle dört köşe kasnak, çerçeve.

\subsection{Dil Derneği (2005). Türkçe Sözlük (2 b.). Ankara: Dil Derneği.}

TDK'den ayrılıp kendi başlarına Türk dilini yönlendirmeyi, kendi zihniyetlerince dile biçim vermeyi hedefleyen bir grubun kurduğu dernek bünyesinde hazırlanan sözlükte etimolojik göndermeler şöyle belirlenmiştir:

Alıntı kelimelerin kaynak dillerindeki asli biçimleri verilmemiş, onun yerine sadece kaynak dil kısaltmasıyla yetinilmiştir:

afiyet $a$. Ar. (“..) Hasta olmama durumu, esenlik. (35. s.)

afsun $a$. Far. Büyü. (35. s.)

afyon a. Yun. 1. Olgunlaşmamış haşhaş kapsüllerine yapılan çizintilerden sızan, sonradan katılaşan süt. 2. (36. s.)

aganta ünl. İt. (...) den. Hareket halindeki bir halatın ya da zincirin, bir süre tutularak bırakılmaması için verilen komut. (36. s.)

agrandisman $a$. Fr. (Fotoğrafçlıkta) Fotoğraflara boyut kazandırma işlemi, büyültme. (36. s.)

kama a. Erm. (.’) 1. Silah olarak kullanılan ucu sivri, iki ağzı da keskin uzun bıçak. (1028. s.)

Kelimenin kaynak dili konusunda iki ayrı dil ifade edilmiş, aslen Farsça olan bir kelime hem Farsça hem de Arapça olarak gösterilmiştir:

divançe $a$. Far. Ar. küçük divan (306. s.)

Türkçeye kaynaklık eden dilin kelimeyi aldığı kaynak diller de verilmiştir.

agnostik a. ve öna. Yun. > Fr. 1. Bilinemezci, bilinemezcilik öğretisini benimseyen (kimse). (36. s.)

agrafi $a$. Yun. > Fr. > yazma yitimi (36. s.)

diyaliz a. Yun. > Fr. kim. 1. kimi cisimlerin gözenekli zarlardan geçebilmesi temeline dayanan bir çözümleme ya da arıtma yöntemi. (307. s.)

kalsit $a$. Lat. > Fr. min. Billurlaşmış doğal kalsiyum karbonatı. (1028. s.)

Kaynak dili Türkçe olan kelimelerde herhangi bir etimolojik açıklama bulunmamaktadır.

\section{6. Çağbayır, Y. (2007). Orhun Yazıtlarından Günümüze Türkiye Türkçesinin Söz Varlığı Ötüken Türkçe Sözlük (Cilt 2). İstanbul: Ötüken.}

Arapça kaynaklı kelimelerin çeviri yazılı hâli, yanında Arap harfli hâli, Türkçenin hangi devresine ait olduğu, kelime türü verilmiş, devamında anlamları sıralanmıştır.

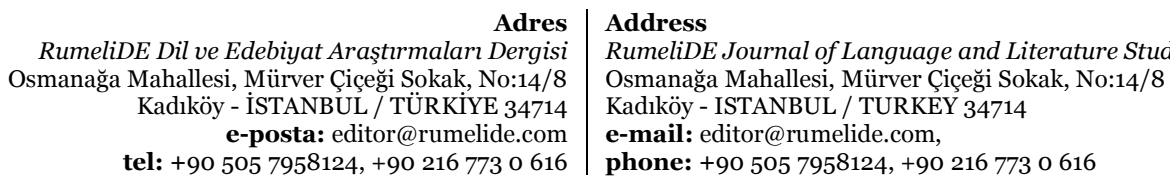


$\mathbf{e v}^{2},[E T . \dot{e v} / \mathrm{eb} / \mathrm{ew} /$ öy/ ef/ öv/ üv/ ev l] is. 1. İnsanların barınması için yapılmış bina. $\{E T\}$ (aynı) [DLT], [Gabain] [EUTS] 2. (1512. s.)

gayb, [Ar. gayb غيب] \{OsT\} is. 1. Göz önünde olmama; gizli olma. 2. (1652. s.)

evar, [Far. evār اواره/اوار] (eva:r) (OsT) is. 1. Hükûmet daireleri ve divana ait defterler. 2. (1513. s.)

Türkçeye kaynaklık eden dilin kelimeyi aldığı kaynak diller de verilmiştir.

histeri, [Yun. hysterikos (rahile ilişkin) > Fr. hystérie] is. tıp 1. Sinir buhranları veya çırpıntılarla dışa vuran sinir bozukluğu, isteri. 2. (1973. s.)

fiks, [Lat. fixus $>$ Fr. fixe] $s f$. Değişmeyen, sabit. (1589. s.)

harran, [Asur. ḥarrānu > Ar. ḥarrān حران] (harra:n) (OsT) is. 1. Yol. 2. (1883. s.)

İki kaynak dil olduğu düşünülmüşse her iki dil de verilmiştir:

dia, [Alm. dia / Fr. diapositive] (diya) is. Saydam bir yüzey üzerine alınmış, projeksiyonda kullanılmaya özgü, pozitif görüntü, slayt. (1208. s.)

Farsça terkipler açılanırken terkibi oluşturan kelimelerin kaynak dili esas alınmıştır. Öncelikle terkibin Farsça olduğu ifade edilmemiştir.

hisseişayia, [Ar. ḥișṣe-i şāyiā حصلُ شُايعه] (hissei şa:yia:) \{OsT\} is. Paylara bölünmemiş mülkiyet üzerinde hak sahibi olunan paylardan her biri. (1973. s.)

didim² $^{2}$, [Soğd. didm / Yun. diadima] (ET) is. Geline gerdek gecesi giydirilen taç. [DLT] (1211. s.)

hot-dog, [Amer. İng. hot-dog (sıcak köpek)] is. Sıcak sosisli sandviç. (1991. s.)

evaze, [Fr. évasè] $s f$. (Elbise eteği için) etek uçlarına doğru genişleyen. (1513. s)

\subsection{Püsküllüoğlu, A. (20o8). Türkçe Sözlük (7 b.). İstanbul: Can.}

Sözlük başında kısaltmalar listesi mevcut. Madde başının kaynak dili kısaltmalarla verilmiş. Hiçbir madde başı için asli imla yer almamıştır:

çengi $a$. Far. çalgı eşliğinde oynamayı meslek edinmiş kadın. (424. s.)

çeşit $a$. Far. 1 türleri bir olan şeylerin kimi özelliklerle ayrılan öbeklerinden her biri, tür. ör. ... 2 ... (425. s.)

çerez a. Yun. 1 yemek öncesi yenilen ya da yemeğe, içkiye eşlik eden zeytin, peynir, meyve, kuruyemiş gibi yiyecekler. (425. s.)

Türkçe kelimelerle veya eklerle genişletilmiş kelimelerin kaynak dilleri iki kaynak dilin kısaltılmasıyla verilmiştir:

çeşitleme a. Far. T. 1 çeşitlemek eylemi. 2 müz. bir müzik parçasını, ana temayı koruyarak, değişik armoni, ezgi ve ritimle söyleyerek yeniden yazma işlemi. 3 ... (425. s.)

büyükşehir b. a. T. Far. > anakent, büyükkent. (363. s.)

Batı dillerinden gelen bazı felsefi kavram ve kelimelerin kaynak dili verilmemiş, hatta açılamak yerine o tür kavram ve kelimelerin sadeleştirmesi sonucu üretilmiş Türkçe karşllıklarına gönderilmiştir:

eklektik $s$. ve $a$. fels. > seçmeci. (616. s.)

eklektizm a.fels. > seçmecilik. (616. s.)

\begin{tabular}{|c|c|}
\hline Adres & Address \\
\hline arl Derg & RumeliDE Journal of Language and Literature Studies \\
\hline soka, No:14/ & Osmanağa Mahallesi, Mürver Çiçeği Sokak, No:14/8 \\
\hline $\begin{array}{r}\text { Kadıköy - İSTANBUL / TÜRKIYE } 34714 \\
\text { e-posta: editor@rumelide.com }\end{array}$ & $\begin{array}{l}\text { Kadıköy - ISTANBUL / TURKEY } 34714 \\
\text { e-mail: editor@ rumelide.com. }\end{array}$ \\
\hline tel: +90 $5057958124,+902167730616$ & phone: +90 5057958124, +90 2167730616 \\
\hline
\end{tabular}


büvet $a$. Fr. > büğet. (362. s.)

Kaynak dili Arapça olan kelimelerde asli imla verilmemiş, sadece kaynak dil kısaltması mevcuttur. Ayrıca bazı kelimeler için parantez içinde kelimenin hecelerinin uzunluk ve kısalığını gösteren işaretleme yer almıştır, ancak bu işaretlemenin kelimenin asli biçimindeki uzunluk ve kısalıkla ilgisi olmayıp sadece telaffuzdaki uzatmayla ilgilidir. Bunun yanında üstten kesme işareti de vurgu için kullanılmıştır:

eyvallah ünl. Ar. (..-) "allahaısmarladık”, hoşça kalın”, "teşekkür ederim”, “evet, öyle olsun” gibi anlamlarda kullanılır. (669. s.)

eza $a$. Ar. (.-) sıkıntı verme, sıkıntı çektirme, üzme, üzgü. (669. s.)

acente $a$. İt. (...) 1 bir kuruluşun yaptığı işi o kuruluş dışında ve onun adına kazanç karşllığı yürüten daha küçük kuruluş... (42. s.)

Bazı kelimelerde yaşanan biçim değişikliği çok ileri seviyede ya da bir özel isimden dönüşen kelime ise o tür kelimelerin asli biçimlerinin verildiği görülmüştür:

iskambil a. Fr. (Fransız Briscambille’in adından) 1 bir yüzünde sayllar ve imler ya da kimilerinde imlerle resimler bulunan ve türlü oyunlar oynamaya yarayan ince kart, oyun kâğıldı... (934. s.).

Kelimelerin kaynak dillerindeki teklik biçimleri verilmemiş, madde başının çokluk biçim olduğu kısaltmayla ifade edilmiştir:

eyyam ç. a. Ar. (.-) esk. günler, zamanlar, elverişli zaman (669. s.).

Kaynak dili Türkçe olan kelimelerde herhangi bir etimolojik açıklama bulunmamaktadır.

\subsection{TDK. (2011). Türkçe Sözlük. Ankara: TDK.}

Madde başı, kelime türü, telaffuzu, kaynak dili ve kaynak dildeki biçimi verildikten sonra açılama verilmiş, kaynak dildeki biçimin kök hali verilmemiştir. Her kaynak dildeki biçim verilmemiş, bazıları gereksiz görülmüştür.

basiret $a$. (basi:ret) Ar. bașiret Gerçekleri yanılmadan görebilme yeteneği, uzağı görüş, seziş, anlayış, kavrayış, sağgörü, vizyon: Örnek cümle. (259b)

diktafon $a$. Fr. dictaphone Bir tür ses alma cihazı. (662a)

Hristiyan öz. a. Rum. din b. Hz. İsa’nın dininden olan kimse, İsevi, Nasrani. (1114a)

hunhar sf. Far. hūnh hūār esk. Kana susamış, kan dökücü. (1115b)

futbol $a$. İng. football sp. Topu, hava veya kafa vuruşları ile karşı kaleye sokma kuralına dayanan ve on birer kişilik iki takım arasında oynanan top oyunu, ayak topu: Örnek cümle. (894a)

\subsection{Ayverdi, İlhan (2011). Misalli Büyük Türkçe Sözlük (2. Baskı). İstanbul: Kubbealtı- Milliyet.}

Madde başı büyük harflerle verilmiş. Kelime alıntı ise asli imlası verilmiş, kaynak diller verilirken Arapça ve Farsça olanlar asli imlasıyla verilip okunuşu da yay ayraç içinde verilmiş, bunların dışındakiler için sadece Latin alfabesi kullanılarak verilmiş. Bir kökten gelişme türemiş veya müştak bir kelimenin kök hali de mevcuttur.

\begin{tabular}{|c|c|}
\hline & \\
\hline eliDE Dil ve Edebiyat Araşstırmaları De & Eournal of Language and Literature Studies \\
\hline 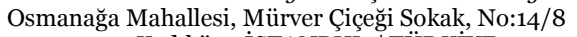 & Mahallesi, Mürver Çiçeği Sokak, No:14/8 \\
\hline Kadıköy - İSTANBUL / & ISTANBUL / TURKEY 34714 \\
\hline $\begin{array}{r}\text { e-posta: editor@rumelide.com } \\
\text { tel: +90 } 5057958124,+902167730616\end{array}$ & $\begin{array}{l}\text { e-mail: editor@rumelide.com, } \\
\text { phone: +90 505 7958124, +90 } 216773 \text { o } 616\end{array}$ \\
\hline
\end{tabular}


ASÍL (اصبل) sıf. ve i. Ar. aṣālet "köklü olmak"tan aṣill) 1. Asâlet sahibi, soylu (kimse), necip: Örnek cümle. (73c. s.)

ÇAY $i$. (Çin. ça-ye; Türkçeye muhtemelen Farsçadan geçmiştir) [Çeşitli dünya dillerinde kullanılan dolaşıcı bir kelimedir.] 1. Açılama: Örnek cümle. (217c. s.)

LAZANYA [ $l$ ince] $i$. (İtal. lasagna < Lat.) Geniş kesilmiş erişteye benzer bir çeşit İtalyan makarnası. (738b. s.)

SINIR $i$. (< sinor < Yun. synoron) 1. Hudut: Örnek cümle. (1102c. s.)

\subsection{Diğer sözlükklerdeki etimolojik açlklamalar}

Üstteki dokuz sözlük dışında şu sözlüklerde de etimolojik açıklamalar şöyledir:

Uç, Tayyibe; Alkan, Kadriye; Büker, Armağan; Dikmen, Aysel; Koçak, Sevinç. (1998). Türkçe Sözlük 1-2. Ankara: Dil Derneği: Madde başının kaynak dili kısaltmalarla verilmekle yetinilmiştir. Sözlük başında kısaltmalar listesi mevcut. Yabancı bir kelimeye karşılık olarak üretilen kelimenin yabancı imlâsı yazılmış, yanına da yabancılığını belirten bir işaret konmuştur.

Tuğlacı, Pars (1971). 2o. Yüzyıl Ansiklopedik Türkçe Sözlük. İstanbul: Pars: Kaynak diller kısaltmayla verilmiş, kısaltmalar listesi başta, "acizane / ācizāne / < Osm. < Ar. ve Far." şeklinde gelişimleri verilmekle yetinilmiş, Arapça ve Farsça kaynaklı kelimelerin asli harfleri verilmemiştir. Batı kaynaklı kelimelerin asli imlası yer almıştır.

Kestelli, Raif Necdet (2004). Resimli Türkçe Kamus (1925). Haz. Recep Toparlı, Belgin Tezcan Aksu, Canan Selvi Kanoğlu, Seyfullah Türkmen. Ankara: TDK: TDK'nin sözlük projelerindendir. Kelimelerin kaynak dilini gösteren kısaltmayla yetinilmiş, kısaltmalar başta listelenmiştir. Kelimenin Arap harfli şekilleri parantez içinde verilmiştir.

Toven, Mehmet Bahaattin (2004). Yeni Türkçe Lügat (1924). Haz. Abdülkadir Hayber. Ankara: TDK: TDK'nin sözlük projelerindendir. Kelimelerin kaynak dilini gösteren kısaltmayla yetinilmiş, kısaltmalar başta listelenmiştir. Kelimenin Arap harfli şekilleri parantez içinde verilmiştir.

Püsküllüoğlu, Ali (1995). Türkçe Sözlük. İstanbul: YKY: Madde başının kaynak dili kısaltmalarla verilmiştir. Sözlük başında kısaltmalar listesi mevcuttur. Hiçbir madde başı için asli imla yer almamıştır.

\section{Genel sözlüklerde etimolojik göndermenin çerçevesi ne olmalı?}

Genel sözlüklerde açıklamalara kadar olan kısımda yer alan unsurlar ve bu unsurların etimolojik nitelikleri bütün bu örnekler göz önüne alınarak ve sözlük kullanıcısına kolay kullanımlık ve yarar düşünülerek şöyle olmalıdır:

1. Madde başı: Genel sözlüklerin madde başları, özel adlar dışında, küçük harfle ve koyu yazılmalıdır. Bir kelimenin büyük yazılması onun cümledeki durumuyla ilgilidir. Cümlenin olmadığı bir ortamda kelime küçük harfle başlamalıdır. Kelimenin yazımında TDK’nin benimsediği yazım esas alınmalıdır. Madde başı koyu olduğu için herhangi bir noktalama veya işarete gerek olmamalıdır. Ancak fiillerin yazımında sondaki \{-mAk\} ekinin yazımına yer verilmemelidir: kitap, yaz-, kalem

\begin{tabular}{r|l} 
Adres & Address \\
RumeliDE Dil ve Edebiyat Araştırmalar Dergisi & RumeliDE Journal of Language and Literature Studies \\
Osmanağa Mahallesi, Mürver Çiçeği Sokak, No:14/8 & Osmanağa Mahallesi, Mürver Çiçeği Sokak, No:14/8 \\
Kadıköy - İSTANBUL / TÜRKIYE 34714 & Kadıköy - ISTANBUL / TURKEY 34714 \\
e-posta: editor@rumelide.com & e-mail: editor@rumelide.com, \\
phone: +90 505 7958124, +90 2167730616
\end{tabular}


2. Kaynak dil: Madde başından sonra eğik/italik olarak kelimenin kaynak dili verilmeli ve bu kısaltmalar TDK’nin benimsediği kısaltma listesine uygun düşmelidir. Farklı kısaltmalar dil araştırmalarında dağınıklığa sebep olmaktadır. Mesela kaynak dil Türkçe ise T., Arapça ise Ar. gibi: kitap $[<A r$.

3. Kelimenin asli biçimi: Türkçe veya alıntı kelimelerin asli biçimleri köşeli parantez içinde gelişim işareti ve kaynak dil ifadesinden sonra Türk çeviri yazı esaslarınca eğik/italik olmalıdır. Başka bir yazı sistemi, mesela Arap, Yunan, Kiril, Çin, Süryani yazı sistemleri gibi, etimoloji sözlüklerinde olabilse de genel sözlükler kamunun tümünü ilgilendirdiği için madde başı olan kelimenin kaynak dilindeki asli biçimini göstermede fazla ve gereksiz duracaktır: kitap $[<A r$. kitāb

4. Anlam değişmesi: Madde başı kelimelerinin kaynak dillerindeki veya Türkçe bir kelimenin önceki devirlerdeki anlamlarında unutulma veya değişme yaşanmışsa onun da normal biçimle anlamının verilmesi gerekir: orak $[<T T$. orak kesici eşya $<E T$. or- kesmek]; kitap $[<A r$. kitāb yazılı nesne $<k t b$ yazmak, kumaş kenarını desenlemek]

5. Kelime türü: Hemen her genel sözlükte kelimenin cümle içindeki görevini gösteren tür kısaltması mevcuttur. Ancak bazı kelimelerin iki türden oldukları unutulmamalıdır Dolayısıyla genel sözlüklerde tür adı yazılacaksa her iki tür kısaltması da eğik olarak yazılmalıdır: kitap [< Ar. kitāb yazılı nesne < $k t b$ yazmak, kumaş kenarını desenlemek] a.; güzel [<ET. köz göz $+e l<k o ̈-$ görmek $+z] a$., $s f$.

6. Dilden dile geçmeler: Madde başı alıntı kelime Türkçeye geldiği dile de başka bir dilden geçmişse bunun gösterilmesi etimolojik bilgilenme açısından gerekli ve faydalıdır: mihanikî $[<A r$. miḩāniki tekdüze < Yun. michanikós mekanik] sf. düşünmeden, ölçülerek değil de yalnızca alışkanlığın verdiği kolaylıkla veya yalnız kasların hareketiyle yapılan (iş, hareket vb.)

7. Türevler: Genel sözlüklerde eğik ve koyu olarak gövde kelimelerin türediği ya da geliştiği ilk kök kelimenin olduğu madde başının açıklamasından sonra türevlerinin yazılması kök ve gövde kelimelerin daha iyi anlaşılmasını sağlayacaktır: kitap [ $<A r$. kitāb yazılı nesne $<k t b$ yazmak, kumaş kenarını süslemek] a. 1. bir araya getirilmiş yazılı veya basılı yapraklardan meydana gelen bütün: Örnek cümle. kitap evi, kitapçı, kitapçıbaşı, kitapçılık, kitaphâne, kitaplamak, kitaplaştırmak, kitaplık, kitapsiz.

\section{Sonuç}

Bir dilde genel sözlük hazırlamak, sözlükçülüğün en zor alanlarından biridir. Çünkü ne çok derine inip kamunun anlamasından uzak akademik veya bilimsel açıklamalara boğulmuş bir metin olmalı; ne de amatörce hislerle, hazırlayanın hazzını tatmin duygusuna cevap olarak hazırlanmış olmalıdır. Tarihten günümüze, kabaca bakıldığında görüleceği üzere, sözlük hazırlayanların büyük kısmı sözlükçülük eğitimi almamış, genel kültürüne güvenip bu işe girişenlerden oluşmaktadır. Öte yandan dil ve edebiyat bölümlerinde sözlükçülük eğitimi almış kişilerde de ötekilerin cesareti bulunmamaktadır.

Genel sözlük hazırlarken belli standartlar benimsenmeli ve bu standartların genel geçer kuralları olmalıdır. Bu kurallardan biri de madde başlarının etimolojik göndermelerinin bulunmasıdır. Etimolojik göndermeler, madde başı kelimelerin daha iyi anlaşılmasında, öğrenilmesinde ve başka kelimelerle irtibatlandırılmasında önemli unsurlardandır.

\begin{tabular}{|c|c|}
\hline & \\
\hline eliDE Dil ve Edebiyat Araşstırmaları De & Eournal of Language and Literature Studies \\
\hline 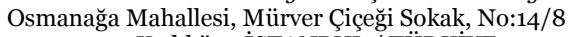 & Mahallesi, Mürver Çiçeği Sokak, No:14/8 \\
\hline Kadıköy - İSTANBUL / & ISTANBUL / TURKEY 34714 \\
\hline $\begin{array}{r}\text { e-posta: editor@rumelide.com } \\
\text { tel: +90 } 5057958124,+902167730616\end{array}$ & $\begin{array}{l}\text { e-mail: editor@rumelide.com, } \\
\text { phone: +90 505 7958124, +90 } 216773 \text { o } 616\end{array}$ \\
\hline
\end{tabular}


Genel sözlüklerde yer alan etimolojik göndermeler, bu sözlükleri kullanan kişilerde Türkçenin komşu dillerini, alt katman ve üst katman etkisinin hangi dillerle ortaya çıtı̆̆ı̆ı, diller arası kelime alışverişini, kelimelerin önceki biçim ve anlamlarıyla güncel biçim ve anlamlarının kıyasını görebilmede dil kullanıcısına yardımcı olacağı ortadadır.

\section{Kaynakça}

Aksan, D. (1995). Her Yönüyle Dil Ana Çizgileriyle Dilbilim (5 b.). Ankara: TDK.

Ayverdi, İ. (2011). Misalli Büyük Türkçe Sözlük (2 b.). İstanbul: Milliyet-Kubbealtı.

Baytop, T. (2007). Türkçe Bitki Adları Sözlüğü (3 b.). Ankara: TDK.

Çağbayır, Y. (2007). Orhun Yazıtlarından Günümüze Türkiye Türkçesinin Söz Varhlğ Ötüken Türkçe Sözlük (Cilt 2). İstanbul: Ötüken.

Dil Derneği (2005). Türkçe Sözlük (2 b.). Ankara: Dil Derneği.

Doğan, D. M. (1982). Büyük Türkçe Sözlük-Türkçe/Osmanhca/Yabancı Dillerden Türkçeye Geçen ve En Çok Kullanılan Kelimeler (2 b.). Ankara: Birlik.

Kaçalin, M. S. (2009). Sözlük. İslâm Ansiklopedisi (Cilt 37, s. 402-414). içinde İstanbul: TDV.

Kaçalin, M. S. (2012). Türk Lugatı. İslâm Ansiklopedisi (Cilt 41, s. 544-545). içinde TDV.

Kadri, Hüseyin Kâzım (I. 1927, II. 1928, III. 1943, IV. 1945). Türk Lugati. İstanbul: Maarif Matbaası.

Karadüz, A. (2009). Sözlük, Sözcük Anlamı ve Öğrenme Üzerine. Turkish Studies International Periodical For the Languages, Literature and History of Turkish or Turkic, 4/4, 636-649.

Kestelli, R. N. (2004). Resimli Türkçe Kamus (1925). (R. Toparl, B. Tezcan Aksu, C. Selvi Kanoğlu, \& S. Türkmen, Dü) Ankara: TDK.

MEB. (1995). Örnekleriyle Türkçe Sözlük (Cilt 2). Ankara: MEB.

Püsküllüoğlu, A. (1995). Türkçe Sözlük. İstanbul: YKY.

Püsküllüoğlu, A. (2008). Türkçe Sözlük (7 b.). İstanbul: Can.

Sertkaya, O. F.. (2012). Etimoloji Nedir Ne Değildir: İsimden İsim Yapan +ay / +ey Eki Üzerine. Ankara Üniversitesi Dil ve Tarih-Coğrafya Fakültesi Türkoloji Dergisi, 19/1, 43-72.

Şemseddin Sami (h. 1317). Kā̄mūs-ı Türkì. Dersa‘ādet: İḳdām Maṭba'ası.

TDK. (2011). Türkçe Sözlük. Ankara: TDK.

Toven, M. B. (2004). Yeni Türkçe Lügat (1924). (A. Hayber, Dü.) Ankara: TDK.

Tuğlacı, P. (1971). 20. Yüzyıl Ansiklopedik Türkçe Sözlük. İstanbul: Pars.

Uç, T., Alkan, K., Büker, A., Dikmen, A., \& Koçak, S. (1998). Türkçe Sözlük (Cilt 1-2). Ankara: Dil Derneği.

Uçman, A. (2010). Şemseddin Sâmi. İslâm Ansiklopedisi (Cilt 38, s. 519-523). içinde TDV.

Usta, H. İ. (2006). Türkçe Sözlük Hazırlamada Yöntem Sorunları. Ankara Üniversitesi Dil ve TarihCoğrafya Fakültesi Dergisi, 46/1, 223-242.

Usta, H. İ. (2010). Sözlükçülük ve Sözlük Araştırmacıllı̆ı̆. Modern Türklük Araştırmaları Dergisi, 7/2, 92-101.

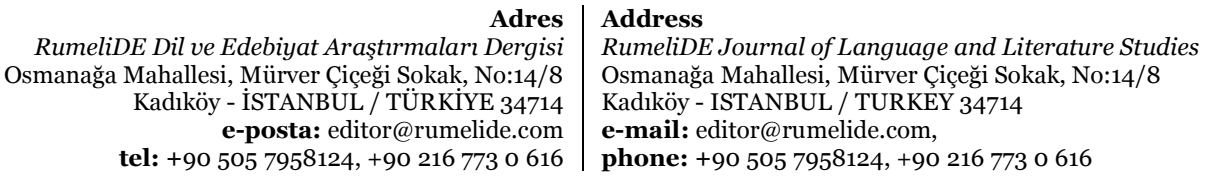

